\title{
Development of a solar/LED lighting system for a plant tissue culture room
}

\author{
Phát triển hệ thống chiếu sáng kết hợp ánh sáng mặt trời và đèn LED cho phòng nuôi cấy mô \\ thực vật
}

\author{
VU, Thi Nghiem¹*; TRAN, Quoc Tien¹; TONG, Quang Cong1; NGUYEN, Manh Hieu1; KIEU, \\ Ngoc Minh1; VU, Ngoc Hai2; VU, Hoang3; SEOYONG, Shin³
}

1 Institute of materials sciences (IMS), VAST, 18 Hoang Quoc Viet, Cau Giay, Hanoi, Vietnam; 2Faculty of Electrical and Electronics Engineering and Phenikaa Institute for Advanced Study, Phenikaa University, Yen Nghia, Ha-Dong District, Hanoi 12116, Vietnam; ${ }^{3}$ Department of Information and Communication Engineering, Myongji University, 116 Myongji-ro, Cheoin-gu, Yongin, Gyeonggi-do 17058, Korea

\begin{abstract}
As the green energy, sunlight provides a friendly-environment and reduces electricity used for lighting. Our target is to enhance the use of natural energy and minimize the consumption of electricity for improving indoor environments. For this reason, a hybrid lighting system, combining sunlight with LEDs for plant tissue culture, are presented. The optical fiber daylighting system consists of three main parts: concentration, collimation beam, and transportation. The concentration part is formed by Fresnel lenses to collect and focus the sunlight into a small area by a non-imaging optical effect. The collimation part consists of optical filters and collimator lenses; the optical filters are used to reflect the ultraviolet (UV) and near infrared (NIR) regions, therefore, only the visible range of the solar light can be transmitted. The transportation part is a large-core optical fiber bundle. To increase the coupling efficiency, the collimator lens is used to expand and to collimate the focused light beam. The collimated light beam is then transported by the optical fiber bundle into a plant tissue culture room. In order to keep the plant tissue culture room at a constant illumination, a lighting control system based on LEDs is used to compensate variations of the natural light. In this paper, a prototype of optical fiber daylighting system and our proposed application will be presented.
\end{abstract}

\begin{abstract}
Ánh sáng mặt trời, một nguồn năng lượng xanh, được sử dụng cho chiếu sáng nhằm mang lại nguồn ánh sáng thân thiện với môi trường và giảm điện năng. Mục tiêu của chúng tôi là tăng cường sử dụng năng lượng tự nhiên và linh kiện tiêu thu điện thấp để cải thiện môi trường ánh sáng trong nhà và giảm tiêu thu điện cho chiếu sáng. vi lý do này, một hệ thống chiếu sáng kết hợp ánh sáng mặt trời với đèn LED để nuôi cấy mô thực vật sẽ được trình bày. Hệ thống chiếu sáng ban ngày bằng sợi quang bao gồm ba phần chính:Bộ phận thu nhận và hội tụ ánh sáng, bộ phận chuẩn trực chùm sáng và bộ phận vận chuyển ánh sáng mặt trời tới nơi cần chiếu sáng. Phần tập trung được hình thành bởi một thấu kính Fresnel để thu thập và hội tu ánh sáng mặt trời vào một vùng nhỏ bằng hiệu ứng quang học không tạo ảnh. Bộ phận chuẩn trực chumg sáng bao gồm bộ lọc quang học và thấu kính chuẩn trực. Bộ phận vận chuyển là các bó sợi quang lõi lớn. Bộ lọc quang học được sử dung để phản xạ vùng cực tím (UV) và vùng hồng ngoại gần (NIR), chỉ cho phần ánh sáng nhìn thấy truyền qua. Để tăng hiệu quả ghép nối, thấu kính chuẩn trực được sử dụng để mở rộng và chuẩn trực chùm ánh sáng hội tụ. Chùm sáng chuẩn trực sau đó được vận chuyển bởi bó sợi quang vào phòng nuôi cấy mô thực vật. Để giữ cho phòng nuôi cấy mô thực vật được chiếu sáng liên tục, một hệ thống điều khiển ánh sáng dựa trên đèn LED để bù lại sự biến đổi của ánh sáng tự nhiên. Trong bài báo này, một nguyên mẫu của hệ thống chiếu sáng ban ngày bằng sợi quang và ứng dụng đề xuất của hệ thống sẽ được trình bày.
\end{abstract}

Keywords: daylighting system; LEDs; plant tisue culture

\section{Introduction}

Light plays an important role in the growth and development of in vitro culture plants. It is an energy source for photosynthesis and physiological processes to produce secondary metabolites. Among numerous factors such as medium composition, gas exchange in the culture vessel, ambient temperature and explant characteristics, light is one of the most important parameters for successful in vitro plant production.
Besides photosynthesis, light in both quantity and quality, is involved in several processes of plant development such as photomorphogenesis and photoperiodism [1, 2, 11]. Due to the importance of light for plant growth, plant tissue culture laboratories normally use a big amount of electrical consumption for artificial light. Artificial lighting generates heat that has to be dissipated by cooling and air conditioning further adding to the electrical load. Recently, LED technology has developed rapidly, with LED lights for plant growth in a controlled environment emerging as a 
useful technology to increase productivity for commercial applications. The most important advantages of LEDs over conventional lighting systems (fluorescent light, halide metal, high-pressure solid or incandescent), include a low power consumption, a long lifespan and a low radiant heat directed at the plant. An overall less heat, allows LEDs to be located much closer to the plant. This close proximity provides a higher concentration of photons that leads to better photosynthetic productivity and at the same time, air-conditioning costs in the growth room are reduced. The application of LEDs in micropropagation can reduce electricity costs from 50 to $75 \%$ in comparison with conventional lighting systems $[4,5]$.

To further reduce electricity and capital costs, as well as improving the plant quality, the alternative of using natural light as light source for micro propagation systems has developed in recent years $[6,7,8,9]$. A low-cost tissue culture technology was introduced in which natural lighting is replaced for artificial lighting. Replacing illumination by natural light for artificial light could bring a low-cost option in tissue culture. Moreover, in vitro cultures, at regulated temperature with air conditioners, adds to the cost but do not contribute to a specific plant quality; plants are adapting not so good in field conditions. In contrast, growth factors of plants under the natural light were better than those using artificial light. Plants are hardener and sturdier under natural light and withstand transplantation better in the field.

In this paper, a hybrid lighting system for the plant tissue culture room will be introduced. Particular attention is paid to the design of an efficient optical fiber daylighting system in combination with LEDs, suitable for plant tissue culture lighting. The next section will present the proposed optical fiber daylighting system; the results of simulation and experiment of sunlight concentration, as well as thermal issues, will be discussed. Proposed applications, discussion and conclusion will be also given.

\section{Design and simulation of the proposed optical fiber daylighting system}

\subsection{Design and components}

In principle, an optical fiber daylighting system includes three main parts as shown in Fig. 1. The first part is to collect and focus sunlight into a small area by a Fresnel lens. This lens is a non-imaging optical device of small volume, lightweight, mass production with low cost and an effective increase in energy density. It can focus light on a small spot, but it does not produce a sharp image [10].

The second section consists of an UV-IR filter and a collimator lens. The UV-NIR filter is used to reflect ultraviolet (UV) and near infrared (NIR) regions, the only visible ranges that can transfer for lighting purpose. The reflection of ultraviolet and near infrared regions is to protect from damage, by ultraviolet and the overheating by infrared light, the optical fiber bundle. The collimator lens is used to collimate the focused sunlight beam before coming into optical fiber bundle to increase the coupling efficiency.

The third section is optical fiber bundles, which have an ability to transfer light for a long distance based on the total reflection principle of optical fibers. They transfer the focused sunlight beam into the interior to be illuminated. The optical fibers were made by poly-methyl methacrylate (PMMA) with a refractive index of 1.49 and a diameter of 2 mm from Huiyuan Plastic Optical Fiber Co., Ltd. (China) [12]. a)

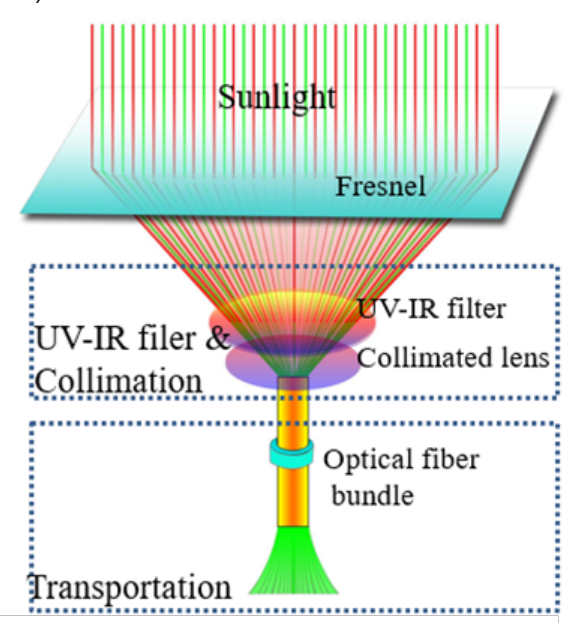

b)

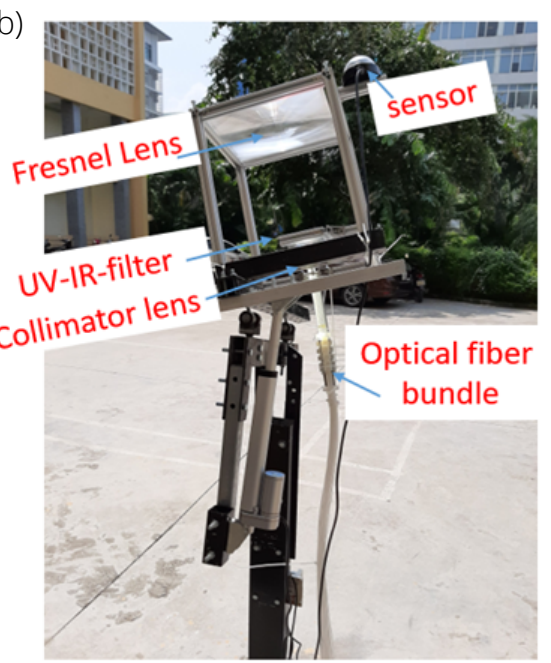

Figure 1. In a), Principle of an optical fiber day lighting system; b) Experimental prototype of an optical fiber day lighting system 
The optical fiber bundle consists of 127 optical fibers, arranged in hexagon shape with a side length of $13 \mathrm{~mm}$. In Fig $1 \mathrm{~b}$, a prototype of the proposed optical fiber daylighting system is given. The Fresnel lens has a focal length of 350 $\mathrm{mm}$ with dimensions of $5 \mathrm{~mm} \times 250 \mathrm{~mm} \times 250 \mathrm{~mm}$ and a groove pitch of $1 \mathrm{~mm}$. It is a commercial linear Fresnel lens made by DiYPRO Co., Ltd. (Korea) [13].

The UV-IR filter (from PIXELTEQ Co., Ltd (China)) reflects the UV and NIR regions of the solar light and transmits more than $98 \%$ of the visible range (395 nm/700 nm) [14]. It can work with stability at high operating temperatures or with varying environmental conditions. The Collimator lens was designed and fabricated by us. It has a spherical shape of $50 \mathrm{~mm}$ of diameter and it was made with silica materials. To define the shape, as well as the position in the optical fiber daylighting system, and to estimate the parameters, the LightTools software was used for calculations. The results are shown in next section.

To increase the efficiency of the system, a two-axis fully automatic tracking system from XIAMEN EMPERY Solar Technology. Co., Ltd (China) [14] was implemented for auto-controlling the system adjustment to follow the sun. The system consists of eight Fresnel lenses, eight UV-IR filters and eight collimator lenses with eight optical fiber bundles. It is mounted on a square steel frame with three sets of small-squares. In the center, a light sensor is mounted with 8 small-squares and 8 Fresnel lenses. The system can capture sunlight with an area of $8 * 250 * 250$ $\mathrm{mm}\left(=0.5 \mathrm{~m}^{2}\right)$. The direct sunlight at the daytime may vary from 50,000 Lux to 100,000 Lux per square meter. Of these units, from 52 to 55 percent are infrared (above 700 $\mathrm{nm}$ ); from 42 to 43 percent are visible (400 to $700 \mathrm{~nm}$ ) and from 3 to 5 percent are ultraviolet (below 400 nm) [16]. It means that, the visible direct sunlight at the daytime varies from 21.250 Lux to 42.500 Lux per square meter. Thus, the system can collect from 10.625 Lux to 21.250 Lux of visible wavelengths.

\subsection{Simulation and implementation of sunlight concentration and thermal issues}

For a long-term operation of the optical fiber daylighting system, the sunlight concentration and heat diffusing in the focused area are the most important aspects. For this reason, the simulation was carried out to verify our theoretical predictions. The simulation provided the focused sunlight beam properties as well as the identification of lenses and their positions to be used for beam collimation. In the first model (Fig. 2a), a light source of 50.000 lux is assumed and a Fresnel lens has a focal length of $350 \mathrm{~mm}$ (dimensions of $5 \mathrm{~mm} \times 250 \mathrm{~mm} \times 250 \mathrm{~mm}$ and groove pitch of $1 \mathrm{~mm}$ ).

In the second model, besides a light source of 50.000 lux and the above-mentioned Fresnel lens, there ws a UV-NIR filter and a collimator lens. Results of the light distribution on the receivers, placed at the focused area of Fresnel lens and placed after the collimator lens, are shown in Fig. 2b and $2 \mathrm{c}$, respectively. It is obvious that, the distribution of light when using a UV-NIR filter and a collimator lens is significantly reduced from $8 \mathrm{E}+4 \mathrm{Lux}$ to $4 \mathrm{E}+4 \mathrm{Lux}$. In order to identify the temperature of the sunlight beam before the coupling into the optical fiber bundle, an infrared thermal camera (FLIR E5: $250^{\circ} \mathrm{C}, 120 \times 90$ pixels, $6.9 \mathrm{mrad}$, real time) was used to capture the thermal image of the sunlight beam at the output of the collimator lens. Fig $2 d$ and 2 e show the thermal images captured at the focused area of Fresnel lens and at the output of collimator lens at mid-day on a sunny day in Hanoi (the outside temperature of $38^{\circ} \mathrm{C}$ ). As it can be seen in the temperature profile, the highest temperature is $119.6^{\circ} \mathrm{C}$ in the focused area of the Fresnel lens; in contrast, the highest temperature is $56.3^{\circ} \mathrm{C}$ when using the UV-NIR filter and collimator lens. This temperature indicates that the optical fiber daylighting system can work properly in Hanoi during the summer season. In fact, the system was tested for the two hottest months of the year (May and June, 2020,) working well during the testing time. 
a)

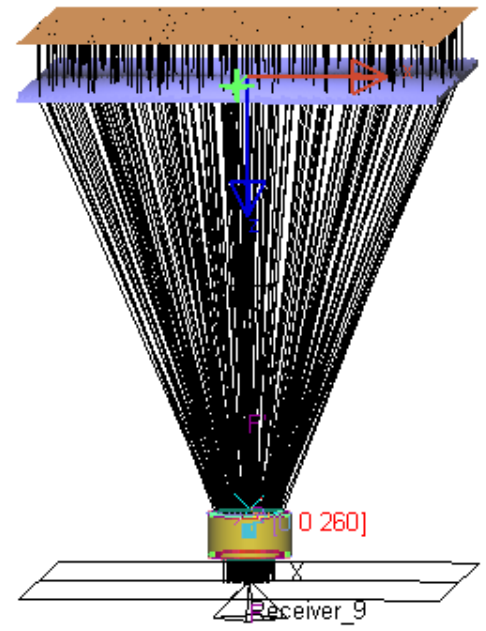

b)

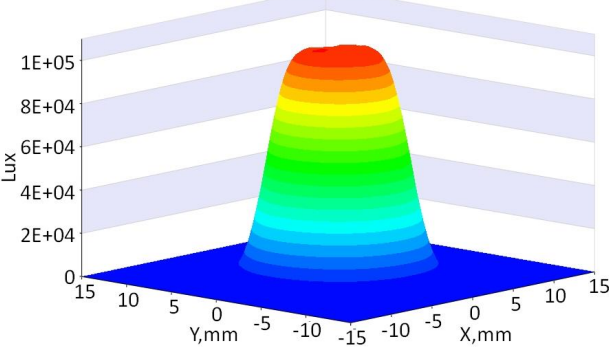

c)

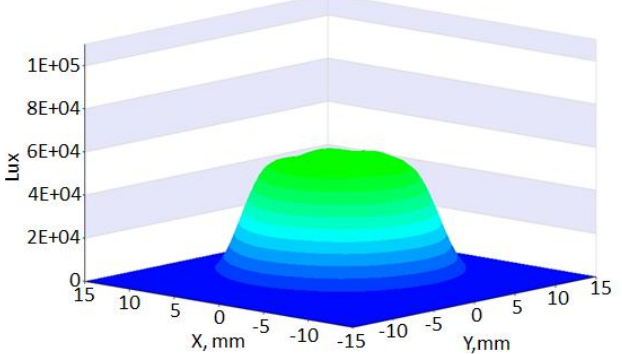

d)
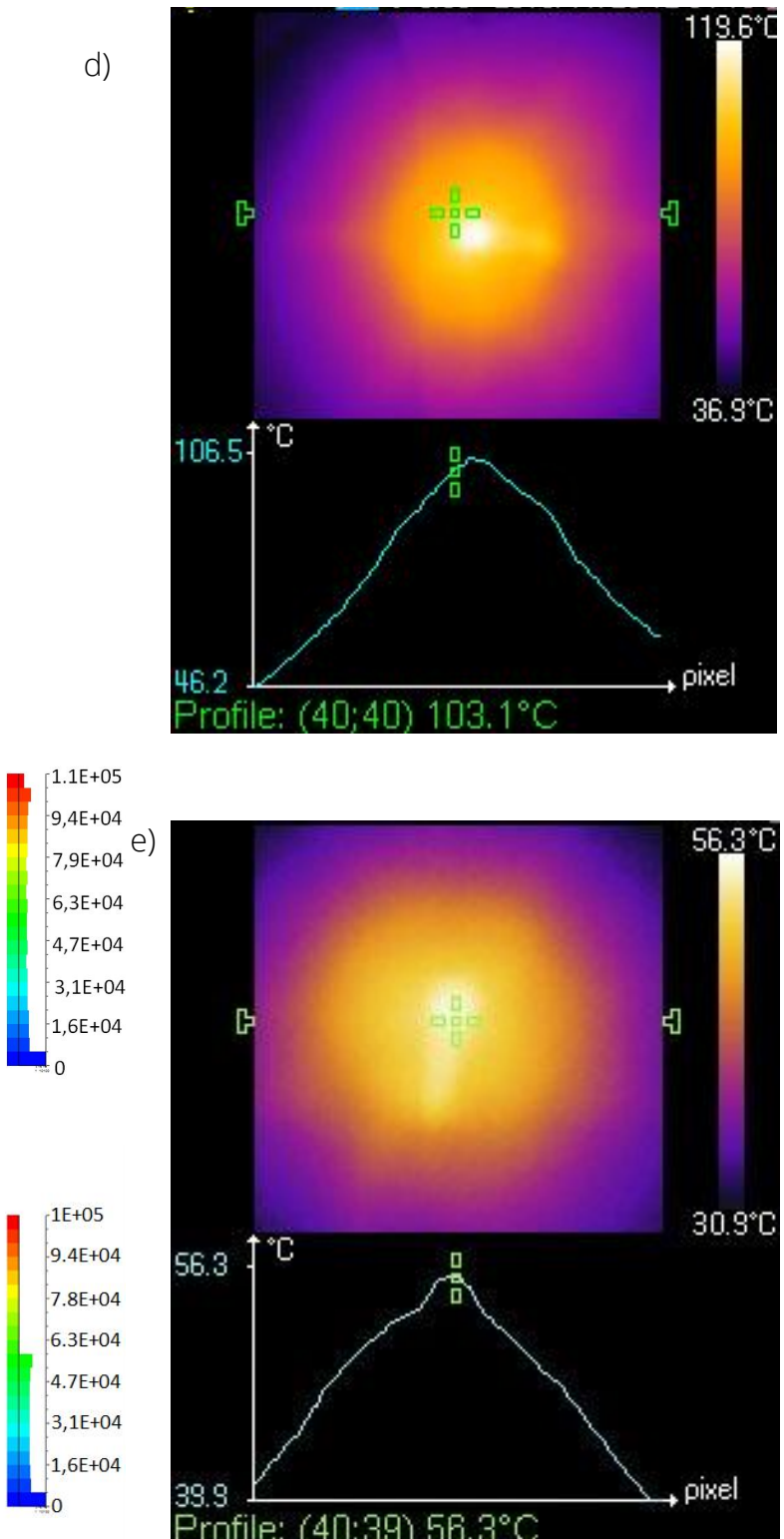

Fig. 2. a) Simulation model using a light source of $50.000 \mathrm{lux}$, a Fresnel lens having a focal length of $350 \mathrm{~mm}$, size: $250 \mathrm{~mm} \times 250 \mathrm{~mm}$; b) resulted simulation of light beam after Fresnel lens and c) resulted simulation of light beam after Fresnel lens and collimator lens; d) thermal measured result of sunlight beam after Fresnel lens; d) thermal measured result of sunlight beam after Fresnel lens and collimator lens.

\subsection{Experimental measurement of lighting output}

The illuminance from the sunlight was measured at different times during several days at different temperature on sunny days from May to June 2020. The site of the application was $21^{\circ} 01^{\prime} 42^{\prime \prime}$ latitude, $105^{\circ} 51^{\prime} 12^{\prime \prime}$ longitude (Institute of Materials Science, VAST). The illuminance was measured on the sunny days. The illuminance at the output of collimator lens were measured from 8:30 a.m. to 4:30 p.m. as plotted in Fig. 3. Three days in May 2020 (19th $-21^{\text {st }}$ May 2020) and three days in June (21 $1^{\text {st }}$ - 23 ${ }^{\text {rd }}$ June 2020) were measured. In May, the temperature varied from $24^{\circ} \mathrm{C}$ to $31^{\circ} \mathrm{C}$ and the measured illuminance varied from $6.500 \mathrm{~lm}$ to $11.300 \mathrm{~lm}$. In June, one of the hottest months in year, an illuminance of about $14.000 \mathrm{Im}$ was measured.

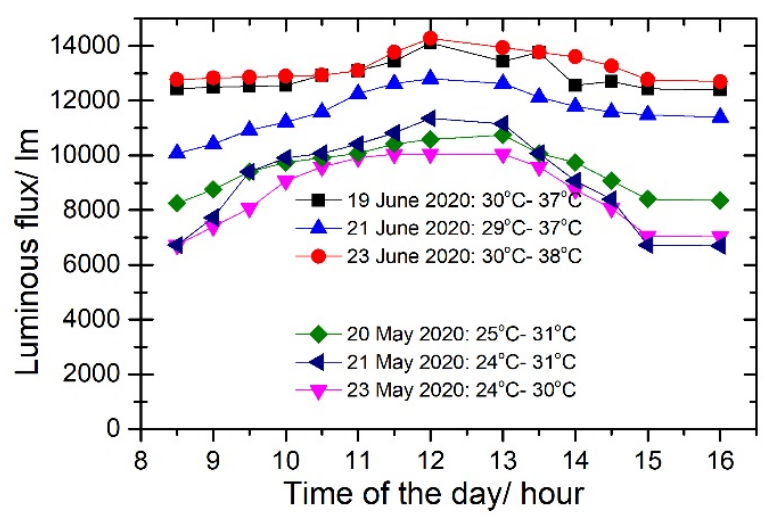

Figure 3. The dependence the output after the collimator lens at different times during several sunny days.

The prototype system reached an optical estimated efficiency of approximately 65\%. This efficiency includes the misalignment between the Fresnel lens, filter and 
collimator lens as well as the loss due to the sun tracking system. In the future, when the system is fabricated through a mass production process, higher optical efficiency is expected to be achieved.

\section{Proposed application and discussion}

Natural lighting for plant tissue culture is investigated in recent decades to reduce electricity and capital costs as well as improving the plant quality. Many types of daylighting systems have been developed with various technologies and solutions but few have been successfully commercialized. Natural lighting, such as greenhouse and light-pipe systems, has several drawbacks in controlling the temperature and in the limitations of distance.

Optical fiber daylighting systems (OFDSs) are a high efficiency performant for both temperature and distance issues. They are still high-cost systems which is a major challenge in the implementation of daylighting systems. The primary purpose of the present work was to find a low cost and highly efficient way to utilize solar energy in daylighting for plant tissue culture. In this study, we proposed a cost-effective approach to an optical fiber daylighting system by integrating several Fresnel lenses. As an initiative for a cost-effective large-scale system, eightFresnel lenses were combined. These systems share a sun tracking system and other infrastructures. The system can

a)

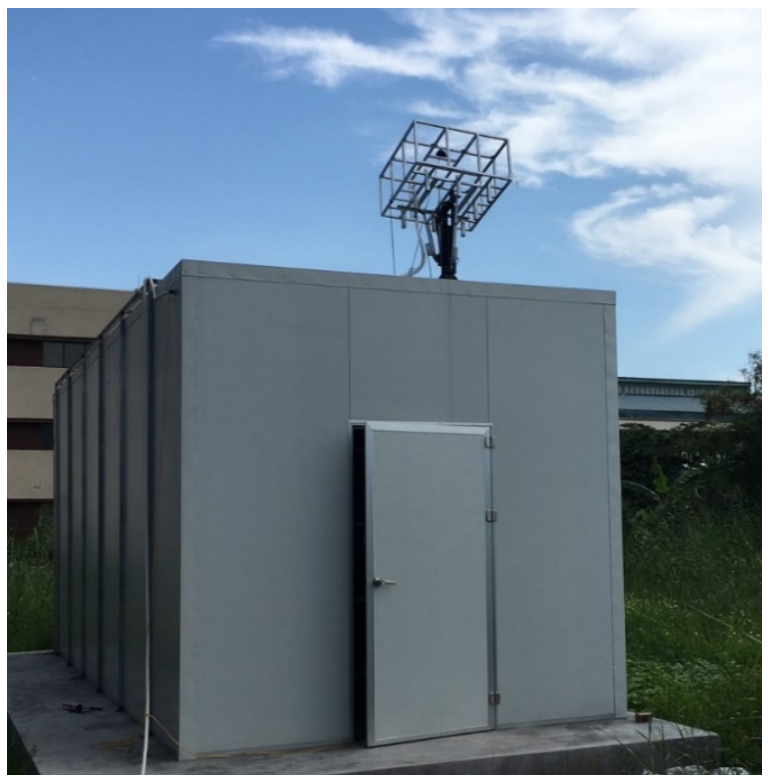

capture sunlight with an area of $8 * 250 * 250 \mathrm{~mm}\left(=0.5 \mathrm{~m}^{2}\right)$, providing from $6.500 \mathrm{Im}$ to $14.000 \mathrm{~lm}$ for interior lighting (see in Fig 3). A typical plant tissue culture requires an average illuminance of about 1000 Lux. At the highest outdoor illuminance (12:00 a.m.), the system can illuminate $14 \mathrm{~m}^{2}$. During the day, when the sunlight in the interior is less than the required value of 1000 lux, artificial light sources (LEDS) should be activated to maintain the same illuminance level.

A schematic depiction of a system is installed on the roof of the plant tissue culture room as see in Fig 4a. The experimental room has been built in the Co Nhue BioExperimental Station, Institute of Biotechnology, Vietnam Academy of Science and Technology. The room is built by isolated thermal panels (Polystyrene Expanded panels) and a steel frame. It has $7.5 \mathrm{~m}$ length, $3 \mathrm{~m}$ width and $3 \mathrm{~m}$ height. To be totally isolated from the outside ambient environment, the room has no window. It has controlled temperature and humidity by air condition and humidifier systems.

To uniformly distribute daylight, light distribution of sunlight and LEDs on shelves for plant tissue in the room were designed as see in Fig 4b. In future works, more OFDSs will be fabricated with the objective of implementing a complete system for whole plant tissue culture room. It will then be evaluating all aspects of the system as well as the growth of plants under daylighting conditions.

b)

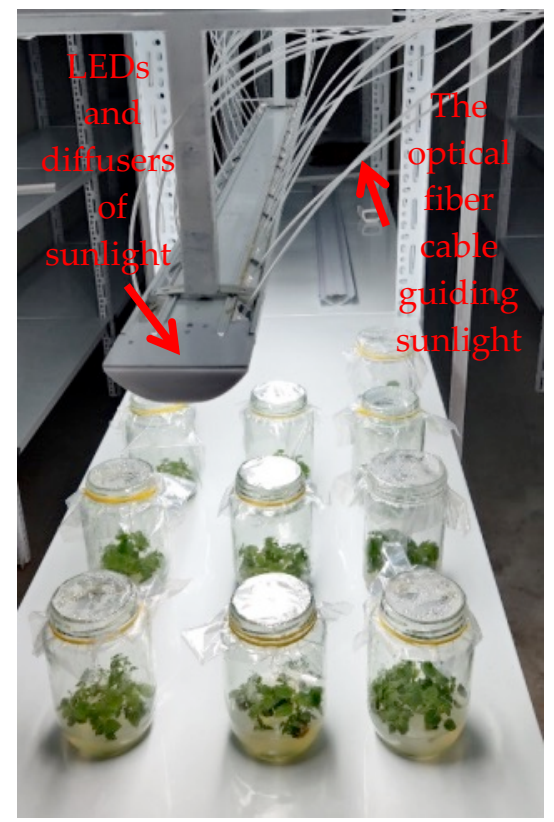

Fig. 4. Captured images of a) the proposed optical fiber daylighting system installing in the roof of plant tissue room (the room having a height of $3.0 \mathrm{~m}$, length $7.5 \mathrm{~m}$ and width of $3.0 \mathrm{~m}$ without window) and b) Light distribution sunlight system and LEDs on shelves for plant tissue in the room

\section{Conclusion}

An optical fiber daylighting system is implemented to save energy, consumed by electric lighting for plant tissue culture. To explore the practical performance of the proposed system, a sample optical system is modelled and simulated using LightTools software to identify optical components. An UV-NIR filter and a collimator lens are efficiently used for collimating the sunlight beam before coupling into optical fiber bundles which are also resolved thermal issues of the system. 
The experimental measurements of temperature of the collimated sunlight beam adapted well for long-term realization. An optical efficiency approximately of $65 \%$ was estimated. Based on the results, the proposed system has a significant potential for its use in plant tissue culture lighting. In future work, we will aim to develop a complete system and evaluate its implementation for a plant tissue culture room. Then, the overall evaluation of the system, as well as the growth of plants under daylighting conditions, will be given more in detailed.

\section{Acknowledgement}

This work was funded by Ministry of Science and Technology of Vietnam under Grant Number NĐT.46. $\mathrm{KR} / 18$

\section{References}

[1] Alix, M. J., Savvides, S., BLAKE, J., Herrmann, R., \& Hornung, R. (2001). Effects of illumination source, culture ventilation and sucrose on potato (Solanum tuberosum) microtuber production under short days. Annals of Applied Biology, 139(2), 175-187.

[2] Batista, D. S., Felipe, S. H. S., Silva, T. D., de Castro, K. M., Mamedes-Rodrigues, T. C., Miranda, N. A., ... \& Torres-Silva, G. (2018). Light quality in plant tissue culture: does it matter. Light quality in plant tissue culture: does it matter. In vitro Cellular \& Developmental Biology-Plant, 54(3), 195-215

[3] DiYPRO Fresnel lenses, "Fresnel Lens for CPV". Retrieved from http://www.diypro.co.kr/

[4] George, P., \& Manuel, J. (2013). Low-cost tissue culture technology for the regeneration of some economically important plants for developing countries. International Journal of Agriculture International Journal of Agriculture, Environment and Biotechnology, 6 (Special Issue), 703-711

[5] Gupta, S. D., \& Jatothu, B. (2013). Fundamentals and applications of light-emitting diodes (LEDs) in in-vitro plant growth and morphogenesis. Plant
Biotechnology Reports, 7(3), 211-220

[6] https://emin.vn/flire5-camera-do-nhiet-flir-e5-250degc-120-x-90-pixels-6-9-mrad-realtimehttps://en.wikipedia.org/wiki/Sunlight

[7] Kodym, A., Hollenthoner, S., \& Zapata-Arias, F. J. (2001). Cost reduction in the micropropagation of banana by using tubular skylights as source for natural lighting. In vitro Cellular \& Developmental Biology, 37(2), 237-242.

[8] Kodym, A., \& Zapata-Arias, F. J. (1998). Natural light as an alternative light source for the in vitro culture of banana (Musa acuminata cV. 'Grande Naine'), Plant Cell, Tissue and Organ Culture, 55(2), 141-145.

[9] Leva, A., \& Rinaldi, L. (Eds.). (2012). Recent advances in plant in vitro culture, BoD, Book on Demand.

[10] Miler, N., Kulus, D., Woźny, A., Rymarz, D., Hajzer, M., Wierzbowski, K., ... \& Szeffs, L. (2019). Application of wide-spectrum light-emitting diodes in micropropagation of popular ornamental plant species: a study on plant quality and cost reduction. In vitro Cellular \& Developmental Biology, 55(1), 99108.

[11] Rehana, S., Ahmed, F., Zeba, N., Husna, A., \& Hossain, F. (2018). Effect of sunlight and artificial light on micropropagation of potato (Solanum tuberosum L.) plantlets, Archives of Agriculture and Environmental Science, 3(2), 151-156.

[12] Sichuan Huiyuan Plastic Optical Fiber Co.Ltd. Retrieved from http://www.pof.com.cn/

[13] Vu, N. H., Pham, T. T., \& Shin, S. (2016). Modified optical fiber daylighting system with sunlight transportation in free space. Optics express, 24(26), A1528-A1545.

[14] XIAMEN EMPERY Solar Technology. Co., Ltd. Retrieved from http://www.emperysolar.com/

[15] Zielinska-Dabkowska, K. M., Hartmann, J., \& Sigillo, C. (2019). LED Light Sources and Their Complex Set-Up for Visually and Biologically Effective Illumination for Ornamental Indoor Plants. Sustainability, 11(9), 2642. 